\title{
Effects of Shredding or Treating Apple Leaf Litter with Urea on Ascospore Dose of Venturia inaequalis and Disease Buildup
}

\author{
Donald K. Sutton, Research Technician, William E. MacHardy, Professor, and William G. Lord, Extension Fruit \\ Specialist, Department of Plant Biology, Spaulding Hall, University of New Hampshire, Durham 03824
}

\begin{abstract}
Sutton, D. K., MacHardy, W. E., and Lord, W. G. 2000. Effects of shredding or treating apple leaf litter with urea on ascospore dose of Venturia inaequalis and disease buildup. Plant Dis. 84:1319-1326.

Ascospores produced on diseased leaves in the leaf litter constitute the primary inoculum causing scab in commercial apple orchards in the northeastern United States. Two sanitation practices, shredding the leaf litter with a flail mower and urea application, were evaluated for their potential to reduce the risk of primary scab. Three measures of a treatment's potential were made: leaf litter density was evaluated to determine reduction of the source or primary inoculum; trapped ascospores were counted to measure the reduction of primary inoculum; and scab lesions on trees and seedlings were counted to determine reduction in disease incidence and severity on leaves and fruit. The results show that in the northeastern United States, shredding the leaf litter in November or April will reduce the risk of scab by 80 to $90 \%$ if all of the leaf litter is shredded. If 10 to $35 \%$ of the leaf litter cannot be shredded because of the limited offset of the flail mower and spread of the tree canopy, then the risk of scab is reduced by 50 to $65 \%$. Urea applied to the leaf litter in November (when approximately 95\% of the leaves had fallen) reduced the number of ascospores trapped by $50 \%$. Urea applied to the leaf litter in April (before bud break) reduced the number of ascospores trapped by $66 \%$. The reductions are discussed in relation to a sanitation action threshold that links sanitation to a strategy that reduces the fungicide dose to control primary scab in an orchard assessed with a moderate amount of foliar scab the previous autumn.
\end{abstract}

Additional keywords: apple scab, black spot, Malus domestica, spore trapping

The repeated application of fungicides throughout the growing season has been the major, if not sole, approach to managing apple scab, caused by Venturia inaequalis (Cooke) G. Wint. (36). During the late $1880 \mathrm{~s}$, growers and horticulturists apparently thought that overwintering scabbed leaves somehow contributed to the development of scab lesions in early spring, because raking and burning leaf litter or treating it with a chemical was recommended in addition to fungicide applications $(53,54,57)$. However, it was not proven experimentally that leaf litter was the source of primary inoculum until near the end of the nineteenth century (13), and it was not until 1924 that a study designed to relate the effect of sanitation practices on scab buildup was published (10). The study, in New Zealand, demonstrated that plowing combined with a reduced lime-sulfur program reduced scab by approximately $84 \%$. A South African study published in 1948 (34) reported

Corresponding author: W. E. MacHardy

E-mail: machardy@christa.unh.edu

Accepted for publication 5 September 2000.

Publication no. D-2000-1020-01R

(C) 2000 The American Phytopathological Society similar results: plowing in combination with four summer fungicide sprays reduced leaf scab $75 \%$ and fruit scab $40 \%$ compared with scab development on trees in an unplowed block that had received the four summer sprays.

The potential of chemicals to eradicate or reduce the overwintering stage of the apple scab pathogen in the leaf litter has been investigated in numerous studies worldwide. The most intensive sanitation research was by Keitt et al. (22-33) in Wisconsin and Palmiter (50-52) in New York from the late 1920s to the early 1940s. Many of the eradicant treatments reduced the ascosporic inoculum over $90 \%$, but even the most effective eradicants did not eliminate the need for fungicide applications, which was the goal of the sanitation research. Apparently, when the investigators felt this goal could not be achieved, the programs shifted to efficacy trials of the new organic fungicides then being developed.

A few studies $(15,16,21,50)$ tested chemical eradicants for their potential to reduce the number of seasonal fungicide applications to control scab, and they all demonstrated that sanitation has the potential to reduce fungicide dose. In Delaware, a ground treatment of $40 \%$ dinitro-orthocresolate (DNOC) or a mixture of sodium nitrate and calcium arsenite in early spring in orchards severely infected the previous year was equal in efficacy to three fungicide sprays applied during the growing season (21). These chemicals are not acceptable today because of their harmful effects on nontarget organisms; nevertheless, they demonstrated that reducing the overwintering stage of the pathogen reduces the amount of fungicide needed to control scab during the growing season.

Surfactants, lime, and fertilizers were also investigated for their eradicant potential $(7,20,43,45)$, and urea was the most effective. Urea applied to trees in autumn before leaf fall or to the leaf litter in autumn or spring before bud break reduced the ascosporic inoculum 50 to $96 \%$. The authors are aware of only two studies that considered the potential of a urea treatment to reduce primary scab lesions. In England, one-half of two large, severely scabbed Bramley orchards received a postharvest, pre-leaf fall application of 5\% urea, and lesions on blossom-spur leaves on the treated trees were reduced by 59 and $46 \%$, respectively, the following spring (6). In France, severely scabbed $(>30 \%$ foliar scab) Golden Delicious and Starking Delicious trees sprayed with $5 \%$ urea after harvest but before leaf fall had $1 \%$ foliar scab at the end of the primary season the following spring (5).

Researchers made no distinction between the high ascospore dose in research orchards used in the sanitation research and the low ascospore dose in commercial orchards, and that may explain why sanitation practices, even practices that reduced primary inoculum $99 \%$, have not been widely endorsed for inclusion in scab management programs. One reason inoculum dose was not considered is that there was no procedure to quantify the ascosporic inoculum in an orchard until 1986 when Gadoury and MacHardy (14) published a procedure for predicting potential ascospore dose (PAD). PAD was calculated for high-inoculum research orchards and for commercial orchards where scab was wellor moderately controlled, and subplots in each orchard that had received different dosages of fungicide were compared for scab incidence and severity $(15,40)$. It became clear that reducing the ascosporic inoculum as much as $99 \%$ by sanitation in a high-inoculum orchard would not be sufficient to warrant eliminating any fungicide sprays the following season. It was also apparent that one to several early-sea- 
son fungicides could be eliminated in orchards that had been well-controlled for scab and that sanitation could eliminate the need for one or more fungicide treatments in orchards that had been moderately controlled for scab. A second reason sanitation has not been more widely incorporated into scab management programs is that there was no economic justification for the cost of a sanitation practice, but that is no longer true. A sanitation action threshold has been proposed for orchards moderately managed for scab in which sanitation eliminates the need for one to several early-season fungicide applications $(37,41)$.

Except for the two limited studies in England and France discussed above, we are not aware of any published study that investigated the potential of a urea treatment in autumn or before bud break to reduce the number of lesions that developed on unprotected trees. Nor, to our knowledge, has the potential of shredding the leaf litter or combining two sanitation practices to reduce the overwintering population of the apple scab pathogen been investigated.

In this study, we investigate the potential of the following sanitation practices to reduce the amount of leaf litter, primary inoculum, and scab lesions on leaves and fruit: (i) treat apple trees with urea in autumn before leaf fall, (ii) treat the leaf litter with urea in autumn and/or spring, (iii) shred the leaf litter in autumn and/or spring, and (iv) a combined autumn leaf shredding and post-leaf fall urea treatment. Preliminary reports have been published $(37,41,56)$.

\section{MATERIALS AND METHODS}

Large-plot study. Large-plot sanitation studies were conducted in two research orchards at the University of New Hampshire and six commercial orchards in New Hampshire and Maine from 1986 to 1990. The orchards and abbreviations used throughout the text were the Mast Road Orchard, Durham, NH (MR), Woodman Farm, Durham (WM), Applecrest, Hampton Falls, NH (AC), Moose Hill, Londonderry, NH (MHI, MHII, MHIII), Gould Hill, Contoocook, NH (GH), Avalock West, Boscawen, NH (AW), Brookdale, Hollis, NH (BR), and Kelly, Acton, ME (KY). Selected blocks were predominantly plantings of McIntosh and Cortland on semidwarfing rootstock. A split-block experimental design was used, with subplots ranging in size from 0.25 to 1.3 ha.
Sanitation treatments, large-plot study. Two sanitation practices were evaluated: (i) treating leaves with a $5 \%$ urea solution (50 $\mathrm{g}$ of agricultural grade urea in $950 \mathrm{ml}$ of water) at a rate of 935 liters/ha and (ii) shredding fallen leaves. The urea solution was applied to the orchard floor after ca. $95 \%$ of the leaves had fallen or in spring before bud break. Autumn urea treatments in 1988 were applied with a Mighty Mac boom sprayer (Model PS-350T, Amerind-MacKissic Inc., Parker Ford, PA). The spring urea treatment in 1990 was applied with a Kinkilder air-blast sprayer (D. E. Kinkilder B.V., Zevenaar, Holland) with the nozzles directed toward the ground. A Seppi M flail mower (Model SMO 200, Seppi M., Eppan, Italy) was used in all shredding trials except at the BR site in 1988, where a Perfect flail mower (Van Wamel, Benedenleevwen, Holland) operated by the grower was used. In 1986 and 1987, leaves were windrowed with a Girdrami brush rake (Borello Inc., Saviglieno, Italy) prior to shredding. In 1988 and 1990, a leaf sweeper attachment for the Seppi flail mower windrowed the leaves as they were being shredded. The offset of the Girdrami brush rake was approximately $0.5 \mathrm{~m}$ greater than the offset of the Seppi mower and removed an estimated 25 to $75 \%$ of the leaf litter from the area swept. For determining the percent leaf litter treated, it was assumed that $25 \%$ of the leaf litter remained in the area of the orchard floor swept with the brush rake. The Seppi brush rake attachment removed an estimated 50 to $100 \%$ of the leaf litter from the area swept. For determining the percent leaf litter treated, it was assumed that all the leaf litter in the area swept by the brush rake was shredded.

Quantifying the leaf litter. Shredded leaf pieces were large enough to be measurable with the point-intercept method of determining leaf litter density (LLD) (14), so the loss of leaf litter in shredded plots was determined by comparing the LLD within treated and untreated subplots in spring before bud break. In 1989 and 1990, the technique reported by Gadoury and MacHardy (14) was modified so that the transect from the base tree passed through the adjacent row to a tree in the next row.

Determining sanitation potential if all leaf litter were shredded. Not all of the leaf litter in an orchard was shredded because of the limited offset of the flail mower and spread of the tree canopy at tractor height. To estimate the percentage of the leaf litter shredded, the area of the orchard floor that was raked and the width of the in-row area not reached by the rake or flail mower were determined, and Table 1 was consulted. The total leaf litter minus the percentage of the leaf litter remaining in the raked area and the area not reached by the rake or flail mower was the estimated percentage of leaf litter shredded.

An estimate of the potential of autumn leaf shredding to reduce the leaf litter, ascospores, or lesion severity if all leaf litter on the orchard floor had been shredded was calculated by the following equation:

$$
R / T=P / 100
$$

where $R$ is the percent reduction in amount of leaf litter, ascospores, or lesions in the shredded plot, $T$ is the percent leaf litter shredded in the treatment plot, and $P$ is the estimated potential reduction if all of the leaf litter were shredded. $R$ and $T$ are known, so solving for $P$, the equation becomes

$$
P=(R / T)(100)
$$

Determining sanitation potential to reduce relative ascospore dose, largeplot study. Relative ascospore dose (RAD) is the total concentration of ascospores per cubic meter of orchard air over the course of the primary (ascospore) season (19). The effect of sanitation treatments on RAD was determined at sites $\mathrm{MR}, \mathrm{AC}$, and $\mathrm{KY}$ by placing four or six volumetric spore traps $(59,60)$ a minimum $10 \mathrm{~m}$ apart within the center of each treatment and check subplot. The spore trap consisted of a $12-\mathrm{V}$ DC blower motor (Herbach and Redemen Co., Mt. Laurel, NJ) mounted within a 5cm-diameter polyvinyl chloride (PVC) pipe that drew air through a $2 \times 20 \mathrm{~mm}$ orifice. Airborne spores impacted on a glass slide mounted in the pipe $1.5 \mathrm{~mm}$ below the orifice. A $12-\mathrm{V}$ battery charger converted the AC power supply available in the orchard to DC. A Variac transformer (Superior Electric Co., Bristol, CT) regulated the current to the battery charger, and this allowed the voltage output to the traps to be adjusted and kept constant at a level that powered the DC blower to pull air through the traps at $18.5 \pm 0.75$ liters $/ \mathrm{min}$. This sampling rate provided an air flow velocity through the collection orifice of $7.7 \mathrm{~m} / \mathrm{s}$. According to the model for determining impaction efficiency of spore traps described by May (42), this sampling rate would result in nearly $100 \%$ impaction of particles the size of $V$. inaequalis asco-

Table 1. Relationship between portion of orchard floor untreated from base of tree toward center of drive isle and percentage of leaf litter shredded in mature plantings of predominantly McIntosh and Cortland apple trees on semidwarfing root stock ${ }^{\mathrm{z}}$

\begin{tabular}{cccccccccccc}
\hline & \multicolumn{10}{c}{ Distance from base of tree $(\mathbf{m})$} \\
\cline { 2 - 11 } & $\mathbf{0 . 0 0}$ & $\mathbf{0 . 2 5}$ & $\mathbf{0 . 5 0}$ & $\mathbf{0 . 7 5}$ & $\mathbf{1 . 0 0}$ & $\mathbf{1 . 2 5}$ & $\mathbf{1 . 5 0}$ & $\mathbf{1 . 7 5}$ & $\mathbf{2 . 0 0}$ & $\mathbf{2 . 2 5}$ \\
\hline \% shredded & 95 & 90 & 75 & 65 & 55 & 45 & 35 & 25 & 20 & 15 \\
\hline
\end{tabular}

${ }^{\mathrm{z}}$ Derived from 15 orchards with 6.1- to 7.6-m tree-row spacing. 
spores. Airflow through the traps was determined with a Kurz Mini Anemometer (Series 490, Kurz Instruments, Carmel Valley, CA).

Trap operation was controlled in the field by a hemp string leaf wetness indicator (LWI) (39). When wet, the hemp string tightened to complete an electric circuit from a $12-\mathrm{V}$ battery to a solid state relay that allowed current to flow to the Variac transformer and activate the traps. Operation of the traps was restricted by a $24-\mathrm{h}$ day/night timer to between 0700 and 1900 $\mathrm{h}$, the time of day when $>90 \%$ of the ascospores are discharged over a season (38). The LWI was also attached to a modified hygrothermograph (39) that provided a record of the hours of trap operation so that the total volume of air sampled for the trapping period could be calculated. The glass slides were removed from the traps at $1900 \mathrm{~h}$ on each day spores were collected. The slides were then labeled and the spore deposits sealed with a coverslip mounted in a gelvatol solution (35 g of grade 40-20 Gelvatol dissolved in $100 \mathrm{ml}$ of distilled water and $50 \mathrm{ml}$ of glycerol) and stored for later counting.

The number of ascospores collected on each slide was estimated by counting at $\times 400$ all ascospores within 10 transects perpendicular to the 22-mm axis of the spore deposit. The first transect was 2.0 $\mathrm{mm}$ from one end of the spore deposit, with subsequent transects spaced $1.5 \mathrm{~mm}$ apart. The area examined was approximately $20 \%$ of the deposit. The total ascospores collected was estimated as

$$
X=5 Y
$$

where $X$ is the estimated total ascospores per slide and $Y$ is the number of ascospores counted. Hirst (19) calculated RAD by summing all the hourly spore densities for the primary (ascospore) season derived from a continuous-recording spore trap. The trap used in the present study was not the continuous-recording type; however, it sampled air at a known rate, i.e., 1.1 $\mathrm{m}^{3} / \mathrm{h}$, so mean hourly ascospore densities for each trapping period could be approximated by dividing the total spores trapped by the number of hours the traps were in operation. The RAD was then calculated by summing the approximated hourly ascospore densities for all trapping periods.

Disease assessment. The seasonal fungicide program to manage scab in each orchard was determined by the grower except that the first fungicide spray was delayed until the green tip, pink, petal-fall, or fruit-set stage of fruit bud development in the center of the treated and untreated check plots. The delayed-first-spray plots consisted of 40 to 200 trees. Delaying the first spray resulted in trees being unprotected by fungicide for one to six infection periods and, thus, provided a useful means to determine the effectiveness of sanitation in reducing scab lesions in the absence of early-season fungicide protection.

Disease severity was assessed soon after petal-fall each year. Leaves on 50 randomly selected extension shoots and 50 fruit clusters per tree on four trees, or leaves on 20 randomly selected extension shoots and 20 fruit clusters per tree on 8 or 10 trees, were assessed in each plot. The number of trees examined depended on the size of the plot and the number of trees the grower was willing to subject to a delayedspray program. All scab lesions observed on the leaves examined in a plot were recorded and the total expressed as disease severity. The effect of sanitation on the buildup of diseased fruit was determined by examining 200 to 500 fruit in delayedfirst-spray and check plots just prior to harvest. Each fruit examined was recorded as scabbed or healthy and the percentage of scabbed fruit expressed as disease incidence.

Seedling study. The effectiveness of autumn leaf shredding in lowering disease incidence and severity was evaluated by comparing lesion severity on leaves on potted seedling trees placed within treated and untreated plots during three rain events at the MR site in 1987 and five rain events at the AC site in 1988. On each day, 12 potted, 3-month-old McIntosh apple seedlings were placed in each treated and untreated plot at $0700 \mathrm{~h}$, removed at $1900 \mathrm{~h}$, and placed in a mist chamber maintained at 20 to $22^{\circ} \mathrm{C}$ for $24 \mathrm{~h}$ to allow infection to continue under conditions of continuous leaf wetness, and finally placed outdoors to incubate under natural environmental conditions. Disease severity on the 12 seedlings from each plot was determined 5 days after the first lesion was observed on a set of seedlings.

Statistical analysis. The effect of autumn sanitation treatments on LLD, RAD, scab severity on leaves of orchard trees and seedlings, and the incidence of scabbed fruit was assessed by analysis of variance (ANOVA) using individual sites (replicates) as a blocking factor. Data on the incidence of scabbed fruit was subjected to arcsine transformation prior to analysis. In order to stabilize site-to-site variation, data on LLD, severity of foliar scab, and incidence of scabbed fruit were logarithmically transformed before ANOVA. Significant differences between treatments were determined at $P=0.05$ and $P=0.10$ using a standard $F$ test. Spring sanitation treatments were not replicated; therefore, statistical analyses were not possible.

Small-plot study. A small-plot study was conducted at the University of New Hampshire's Woodman Research Farm and Mast Road Orchard in Durham in 1989 to 1990 and at the Kingman Research Farm in Madbury from 1992 to 1996 . Three sanitation practices were evaluated: (i) shred the leaf litter with a Seppi M flail mower in autumn and/or spring, (ii) treat trees with a
$5 \%$ urea solution in autumn prior to leaf fall, and (iii) treat fallen leaves with a $5 \%$ urea solution in autumn after approximately $95 \%$ leaf fall or in spring before bud break.

Sanitation treatments, small-plot study. In 1989-90, the first year of the study, the effect of an autumn pre-leaf fall application of urea and a spring application of urea on ascospore dose was evaluated on severely scabbed leaves placed equidistant from each other within $50-\mathrm{cm}-$ square frames placed on a sod field. In the pre-leaf fall urea treatment, three McIntosh trees at the Mast Road Orchard were sprayed with the urea solution on 12 October 1989 with a Solo airblast sprayer (Model 419/32, Solo Kleinmotoren, Sindelfingen, Germany). On 19 October 1989, 150 severely scabbed leaves, i.e., >10 visible lesions per leaf, were collected from the sprayed trees and placed in hardware cloth cages for overwintering on the orchard floor. A set of 150 severely scabbed leaves collected from three unsprayed trees and overwintered similarly served as a check. The leaf surface exposed on each leaf during overwintering was marked for future reference when the leaves were placed within the wooden frames, as pseudothecia emerge on the leaf surface exposed during overwintering (13). On 24 April 1990, the cages were collected and four sets of 16 urea-treated leaves were selected at random. Each set was placed in a separate frame, as described above. Overwintered untreated leaves were selected and placed in the wooden frames as described for treated leaves. In the spring urea trial, 128 severely scabbed leaves were collected from beneath unsprayed McIntosh trees at the Mast Road orchard on 24 April 1990. The leaves were divided into eight sets of 16 leaves, and each set was placed under a wire mesh frame. On 2 May 1990, four frames were selected at random, and the area within each frame was uniformly sprayed with $23 \mathrm{ml}$ of a $5 \%$ urea solution (equivalent to 935 liters/ha) with a hand-held spray bottle. The remaining four frames served as unsprayed check plots. During a rain event, ascospores were collected from a shelter spore trap placed in the center of each plot.

In 1992 to 1996, the small-plot study was conducted at the Kingman Farm research orchard. In post-leaf fall urea treatments, a wooden frame was placed $0.75 \mathrm{~m}$ from the base of a McIntosh tree and the area within the frame sprayed with the urea solution, as described above. Each plot in the leaf-shredding study was $2 \times 5$ $\mathrm{m}$ centered on a McIntosh tree. A completely randomized block design was used each year, with each treatment and untreated check plot replicated four times.

Determining sanitation effect on relative ascospore dose. An enclosed shelterspore-trap (Fig. 1) was developed to collect ascospores discharged from a $0.25 \mathrm{~m}^{2}$ 
sampling area within a treatment or check plot. A wire-mesh screen stretched over a wooden frame prevented leaves from moving into, or out of, the sampling area (Fig. 2). The shelter was an A-framed structure $50 \mathrm{~cm}^{2}$ at the base and $35 \mathrm{~cm}$ high with Plexiglas side panels to allow light to enter the shelter. An impactiontype spore trap was inserted through a 5$\mathrm{cm}$ hole drilled in the center of the top brace of the shelter and positioned so that the trap orifice was $25 \mathrm{~cm}$ above the ground. The shelter-spore-trap consisted of a 12-V DC blower motor (Herbach and Radman, Mt. Laurel, NJ) housed within a 20 -cm length of 5-cm-diameter schedule

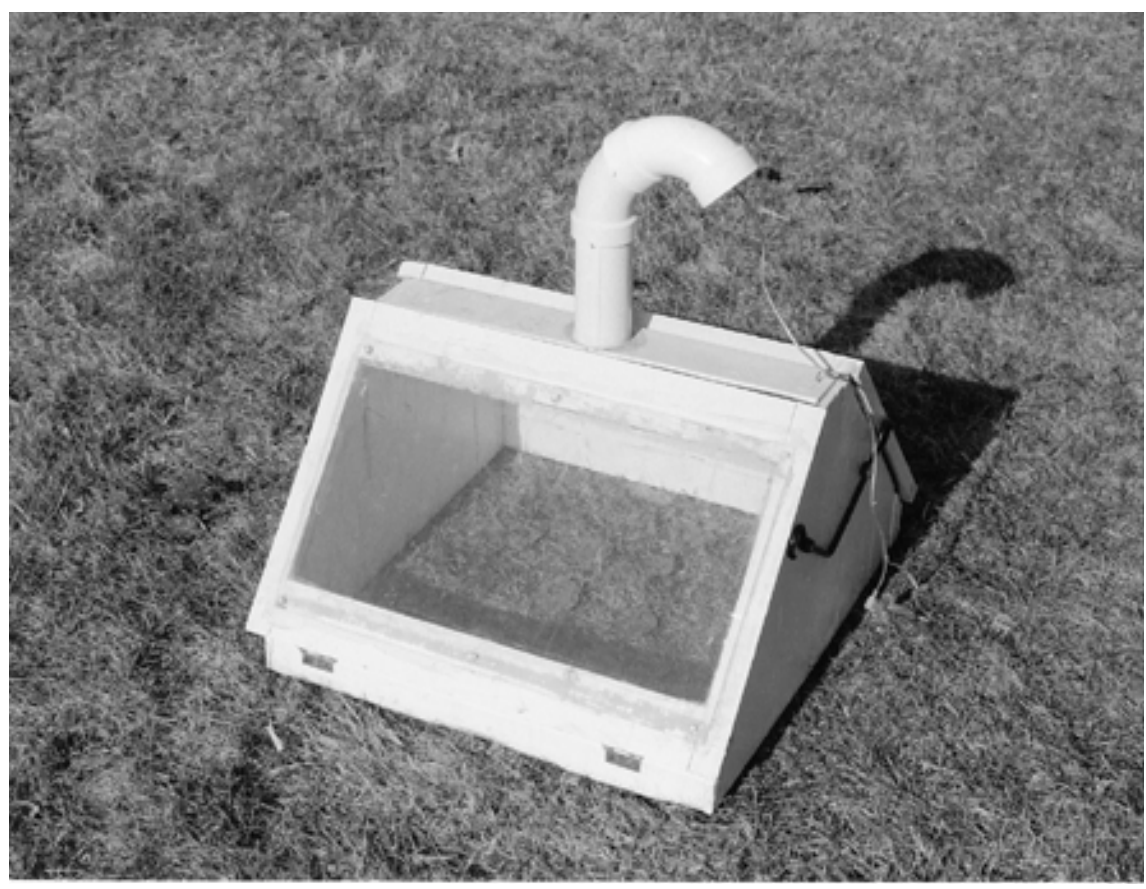

Fig. 1. Shelter spore trap.

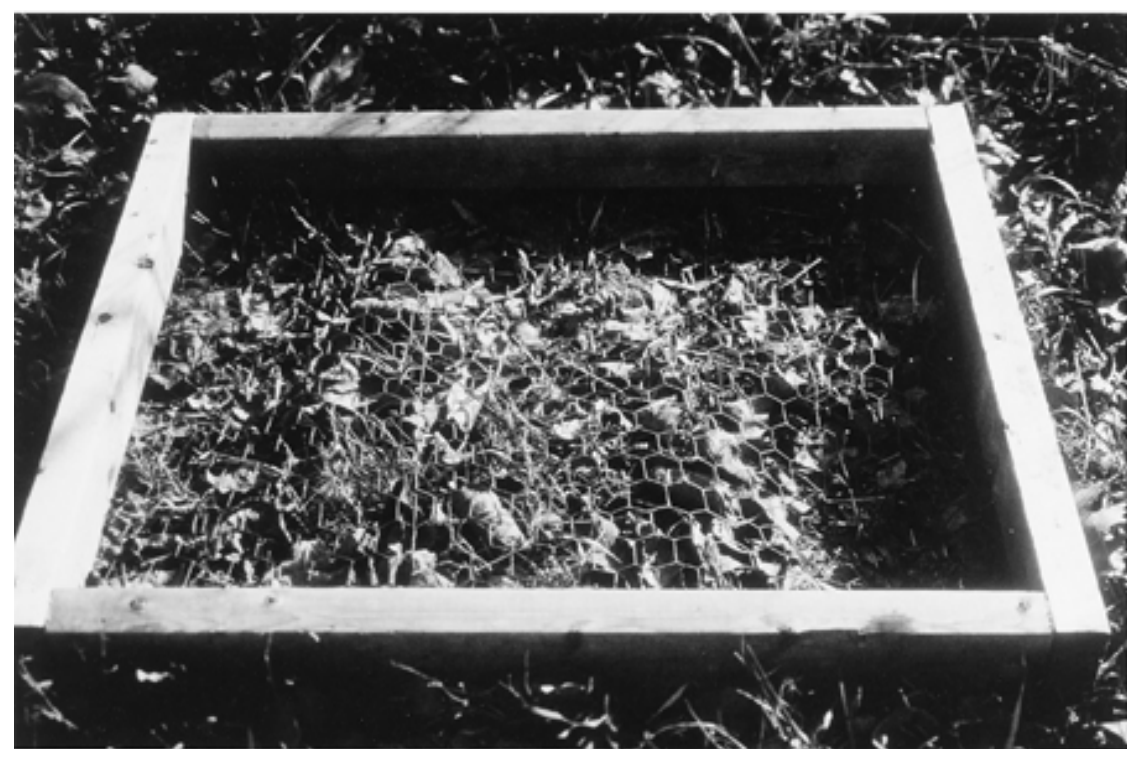

Fig. 2. Close-up view of wooden frame with wire mesh screen. Shelter spore trap shown in Figure 1 was placed on frame during rain events, and spore trap was activated to collect airborne ascospores of Venturia inaequalis discharged from scabbed apple leaves under wire mesh. charger to the traps was regulated by a Variac transformer, as described above.

The shelter-spore-trap was adjacent to the sampling area except when spores were collected. When the leaf litter became thoroughly wetted by rain, the shelter traps were placed on the wooden frames, the spore traps were turned on, and ascospores were collected for 4 to $12 \mathrm{~h}$ during the daytime. When the sampling period ended, the glass slides were removed from the traps and the spore deposits sealed in gelvatol solution and stored for later counting as described above.

Statistical analysis. A treatment effect on ascospore dose was evaluated using ANOVA. Because standard deviation increased as the treatment mean number of ascospores increased, the data on ascospore collections were logarithmically transformed prior to ANOVA. Significant differences in ascospores trapped between treatment plots and check plots were determined at $P=0.05$ and $P=0.1$ using a standard $F$ test.

\section{RESULTS}

Urea treatment: reduction in ascospores. In the large-plot study (Table 2), urea applied in spring before bud break in 1990 at the KY site reduced the RAD by $74 \%$. In a 1-year trial in the small-plot study (Table 3), urea applied to trees on 12 October 1989, before leaf fall, reduced the number of ascospores trapped by $97 \%$. In a 2-year trial, urea applied to the leaf litter on 8 November 1993 and 16 November 1995 (when approximately $95 \%$ of the leaves had fallen) reduced the number of ascospores trapped by 42 and $58 \%$, respectively. In a 5-year study, urea applied to the leaf litter in spring reduced the number of ascospores trapped by 44 to $86 \%$ (average reduction $70 \%$ ).

Urea treatment: reduction in amount of leaf litter and lesions (Table 2). Urea applied to the leaf litter in autumn at the AW site in 1988 did not reduce the amount of leaf litter before bud break, nor did it significantly reduce foliar lesion severity on orchard trees. Urea applied in spring at the KY site in 1990 reduced the number of lesions on leaves $80 \%$ and the incidence of scabbed fruit $41 \%$.

Leaf shredding: reduction of ascospores. In the large-plot study (Table 2), the RAD was reduced 54 and $56 \%$ in plots where leaves were shredded in autumn at the MR and AC sites, respectively. In a 4year study in the small-plot orchard (Table 3 ), the reduction in number of ascospores trapped (i) ranged from 34 to $91 \%$ (average reduction $72 \%$ ) in plots shredded in autumn when $95 \%$ of the leaves had fallen, (ii) ranged from 50 to $85 \%$ (average reduction $75 \%$ ) in plots shredded in spring before bud break, and (iii) ranged from 57 to $89 \%$ (average reduction $78 \%$ ) in plots shredded in autumn and spring. The reductions were significant at $P=0.05$, with the 
exception of the autumn 1991 leaf shredding treatment.

Leaf shredding: reduction in amount of leaf litter and lesions (Table 2). Shredding the leaf litter in autumn significantly $(P=0.05)$ reduced the amount of leaf litter, foliar lesions on trees, and the incidence of scabbed fruit by 52,65 , and $46 \%$, respectively. The reduction in amount of leaf litter ranged from 38 to $73 \%$, the reduction in the severity of foliar lesions ranged from 29 to $100 \%$, and the reduction in the incidence of scabbed fruit ranged from 15 to $71 \%$. The number of lesions on seedlings placed in the plots where leaves were shredded in autumn was reduced by 33, 71, and $82 \%$ for the three exposure dates at the MR site, and by 43, 66, 66, 77, and $84 \%$ for five exposure dates at the $\mathrm{AC}$ site. The reduction in number of lesions for all exposure dates at the MR and AC sites averaged 77 and $66 \%$, respectively. Shredding the leaf litter in spring at the KY site in 1990 reduced the number of lesions on leaves by $80 \%$ and the incidence of scabbed fruit by $63 \%$.

The potential of shredding to reduce the number of ascospores and lesions if all leaf litter were shredded. The percent leaf litter shredded at the nine sites ranged from 65 to $95 \%$. It is estimated that shredding all of the leaf litter in autumn at the six sites would have reduced the amount of leaf litter, the number of lesions on leaves, and the incidence of scabbed fruit by 69 , 79 , and $59 \%$, respectively. At the MR and AC sites, it is estimated that shredding all of the leaf litter in autumn would have reduced the number of ascospores and the number of lesions on seedlings placed in the shredded plots by 71 and $92 \%$, respec- tively. Each reduction can be considered a measure of the reduction of risk of primary scab resulting from shredding the leaf litter in autumn, and considered collectively, shredding the entire orchard floor in autumn is estimated to have the potential to reduce the risk of primary scab by $77 \%$.

Combined leaf shredding and urea treatment: reduction in amount of leaf litter and lesions (Table 2). Urea applied to the leaf litter in autumn before shredding at the AW site in 1988 did not result in a greater reduction in amount of leaf litter than the reduction caused by shredding. The combined treatment reduced lesion severity and the incidence of scabbed fruit 42 and $65 \%$, respectively, compared with $29 \%$ lesion severity and $75 \%$ incidence of scabbed fruit in the plot that had received only the shredding treatment.

\section{DISCUSSION}

Urea treatment: reduction of ascospore dose, leaf litter density, and lesion buildup. In the small-plot study, urea was most effective when applied to the trees in autumn before leaf fall, and the percent reduction in number of ascospores trapped was comparable to the percent reduction in the number of pseudothecia or ascospores reported in several other studies $(6,8,9,11,17,44,46,55,58)$. The treatment was not repeated because of grower concern that urea applied to the trees in late autumn may result in nitrogen accumulation in buds at a level that may stimulate new growth resulting in winter injury under some conditions. We are not aware of any published data to support this idea. Oland (49) found no evidence that urea was injurious, but considering that winter conditions in England may have been less severe, we decided to evaluate other treatments. However, the nearly complete elimination of ascospores collected from leaves sprayed with urea while on the tree warrants further testing of this treatment, in conjunction with a study investigating the potential effect of autumn applications of urea on tree hardiness.

A post-leaf fall treatment of urea was usually more effective when applied in spring, and the percent reduction in ascospores trapped was similar to the reduction in pseudothecia or ascospores reported for a spring urea treatment in other studies $(6,18,44)$. The two least effective spring urea treatments were in 1993 and 1994. Snow cover through much of the winter in 1993 and 1994 that did not disappear until shortly before the sanitation treatments may somehow have contributed to the poor performance, although the snow cover did not appear to have a negative impact on the performance of the leaf shredding treatment those 2 years. The post-leaf fall autumn urea treatment was the least effective of all treatments tested, with the results showing that applying urea to the leaf litter after leaf fall in the northeastern United States would reduce the risk of primary scab approximately $50 \%$.

In the large-plot study, applying urea to the leaf litter before shredding in autumn in 1988 did not improve on the performance of shredding alone, and the results are suggestive that the combined autumn treatment would offer no advantage over shredding. However, the combined treatment was evaluated only once, so it should be repeated before ruling out this treatment. Burchill (6) in England, reported that the

Table 2. Large plot study: percent reduction in leaf litter density, relative ascospore dose of $V$. inaequalis, severity of scab lesions on leaves of potted seedlings placed in orchard during rain events, severity of scab lesions on orchard leaves, and preharvest incidence of scabbed fruit resulting from sanitation practices aimed at reducing the amount of ascosporic inoculum

\begin{tabular}{|c|c|c|c|c|c|c|c|c|c|c|c|c|c|c|c|}
\hline \multirow[b]{4}{*}{ Site } & \multirow[b]{4}{*}{ Date } & \multirow{4}{*}{$\begin{array}{l}\text { Sanitation } \\
\text { treatment }^{\mathrm{x}}\end{array}$} & \multirow{4}{*}{$\begin{array}{c}\text { First } \\
\text { fungicide }\end{array}$} & \multirow{4}{*}{$\begin{array}{c}\text { Infection } \\
\text { periods } \\
\text { unprot. }\end{array}$} & \multirow{4}{*}{$\begin{array}{c}\text { \% leaf } \\
\text { litter } \\
\text { shredded }\end{array}$} & \multicolumn{10}{|c|}{ Reduction $(\%)^{\mathrm{v}}$} \\
\hline & & & & & & \multirow{2}{*}{\multicolumn{2}{|c|}{$\begin{array}{c}\text { Leaf } \\
\text { litter density }\end{array}$}} & \multirow{2}{*}{\multicolumn{2}{|c|}{$\begin{array}{c}\text { Relative } \\
\text { ascospore dose }\end{array}$}} & \multicolumn{4}{|c|}{ Scabbed leaves } & \multirow{2}{*}{\multicolumn{2}{|c|}{ Scabbed fruit }} \\
\hline & & & & & & & & & & \multicolumn{2}{|c|}{ Seedlings } & \multicolumn{2}{|c|}{ Trees $^{w}$} & & \\
\hline & & & & & & Act. & Pot. & Act. & Pot. & Act. & Pot. & Act. & Pot. & Act. & Pot. \\
\hline \multicolumn{16}{|c|}{ Replicated treatments } \\
\hline MR & 25 Nov 86 & AS & $\ldots$ & $\ldots$ & 80 & $\ldots$ & $\ldots$ & 54 & 68 & 77 & 96 & $\ldots$ & $\ldots$ & 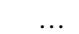 & $\ldots$ \\
\hline WM & 24 Nov 86 & AS & $\mathrm{P}$ & 3 & 70 & $\ldots$ & $\ldots$ & $\ldots$ & $\ldots$ & $\ldots$ & $\ldots$ & 58 & 82 & 59 & 84 \\
\hline $\mathrm{AC}$ & 25 Nov 87 & AS & $\mathrm{P}$ & 2 & 75 & 47 & 64 & 56 & 74 & 66 & 88 & 83 & 99 & 26 & 34 \\
\hline MHI & $26 \operatorname{Nov} 87$ & AS & PF & 6 & 75 & 67 & 87 & $\ldots$ & $\ldots$ & $\ldots$ & $\ldots$ & 100 & 100 & 31 & 41 \\
\hline MHII & 1 Dec 88 & AS & $\mathrm{PF}$ & 5 & 75 & 44 & 59 & $\ldots$ & $\ldots$ & $\ldots$ & $\ldots$ & 69 & 92 & 48 & 63 \\
\hline $\mathrm{GH}$ & 30 Nov 88 & AS & PF & 5 & 90 & 73 & 81 & $\ldots$ & $\ldots$ & $\ldots$ & $\ldots$ & 70 & 78 & 71 & 78 \\
\hline $\mathrm{BR}$ & 21 Nov 88 & AS & $\mathrm{PF}$ & 3 & 65 & 42 & 65 & $\ldots$ & $\ldots$ & $\ldots$ & $\ldots$ & 43 & 66 & 15 & 23 \\
\hline AW & 22 Nov 88 & AS & FS & 6 & 85 & 38 & 44 & $\ldots$ & $\ldots$ & $\ldots$ & $\ldots$ & 29 & 34 & 75 & 88 \\
\hline \multicolumn{4}{|c|}{ Mean percent reduction } & 77 & $52^{y}$ & 69 & $55^{\mathrm{y}}$ & 71 & $71.5^{y}$ & 92 & $65^{y}$ & 79 & $46^{y}$ & 59 & \\
\hline \multicolumn{16}{|c|}{ Nonreplicated treatments ${ }^{\mathrm{z}}$} \\
\hline AW & 22 Nov 88 & $\mathrm{AS}+\mathrm{AU}$ & FS & 6 & 85 & 38 & 44 & $\ldots$ & $\ldots$ & $\ldots$ & $\ldots$ & 42 & 49 & 65 & 76 \\
\hline AW & 22 Nov 88 & $\mathrm{AU}$ & FS & 6 & $\ldots$ & 0 & 0 & $\ldots$ & $\ldots$ & $\ldots$ & $\ldots$ & 11 & 11 & 45 & 45 \\
\hline KY & 14 Apr 90 & SS & GT & 1 & 95 & $\ldots$ & $\ldots$ & 89 & $\ldots$ & $\ldots$ & $\ldots$ & 80 & 80 & 63 & 63 \\
\hline KY & 14 Apr 90 & SU & GT & 1 & $\ldots$ & $\ldots$ & $\ldots$ & 74 & $\ldots$ & $\ldots$ & $\ldots$ & 80 & 80 & 41 & 41 \\
\hline
\end{tabular}

${ }^{\mathrm{v}}$ Act. = actual: percent reduction determined from percent leaf litter shredded. Pot. = potential: percent reduction if $100 \%$ of the leaf litter was shredded.

${ }^{w}$ Percent reduction in severity of foliar scab on trees that did not receive their first fungicide spray until after 1-6 infection periods had occurred.

${ }^{\mathrm{x}} \mathrm{AS}=$ autumn shredding; $\mathrm{AU}=$ autumn urea; $\mathrm{SS}$ = spring shredding; $\mathrm{SU}=$ spring urea.

y Reduction significant at $P=0.05$ by ANOVA blocked by orchard.

${ }^{\mathrm{z}}$ Reduction in a single nonreplicated trial. 
effect of urea on ascospore productivity decreased in late-autumn applications. The late application dates in the present study are thought to be the main cause of the limited effectiveness of the post-leaf fall autumn urea treatments. A post-leaf fall urea treatment may not be practical in the northeastern United States until a suitable chemical is found that will accelerate leaf abscission. An earlier leaf fall should also increase the effectiveness of leaf shredding.

Leaf shredding: reduction of ascospores. In the small-plot study, shredding the leaves in autumn or in spring resulted in similar percent reductions of ascospores trapped each year, and there was no further reduction when the leaf litter was shredded in autumn and again in spring. Each treatment (autumn, spring, or combined autumn and spring) resulted in similar reductions of ascospores trapped in 3 of the 4 years, but the autumn leaf-shred treatment in 1991, the spring leaf-shred treatment in 1992, and the combined treatment in 199192 resulted in substantially smaller reductions of ascospores trapped compared with the other 3 years. In 1991, the leaf litter was not shredded until 16 December because of difficulties with the flail mower, and the late treatment date and poor performance of the repaired mower are believed responsible for the poor results of the shredding treatment that year compared with the other 3 years. Most pseudothecia form within 4 weeks after leaf fall in the northeastern United States (12); therefore, pseudothecia may have already developed before the leaves were shredded, and low temperatures may have slowed or stopped leaf decomposition processes or microbial activities detrimental to $V$. inaequalis after the leaves were shredded. The spring shredding treatment in 1992 was earlier than in other years, but the leaves appeared to be as shredded as in other years, and it is not clear why the reduction in number of ascospores was not greater. It was expected that the spring urea or shredding treatment would increase in effectiveness as the number of days increased between the treatment and green tip, but no such relationship occurred. The 27 days between the spring shredding treatment and green tip in 1992 was longer than in other years and had the least effect on ascospore dose, and urea applied 7 days after green tip was more effective in reducing ascospores than treatments applied 2 to 10 days before green tip and as effective as urea applied 18 days before green tip. Weather following a treatment, particularly temperature and rain events, was most likely the major factor influencing a treatment's effectiveness, but the study was not designed to evaluate the influence of weather variables on treatment effectiveness.

Leaf shredding: reduction of leaf litter density and lesion buildup. Variability in the reduction in amount of leaf litter

Table 3. Small-plot study: percent reduction of ascospores of Venturia inaequalis trapped from McIntosh and Cortland leaves that had been treated with a 5\% urea solution in autumn before leaf fall, from leaf litter that had been treated with a 5\% urea solution in autumn or spring, or from leaf litter that had been shredded with a flail mower in autumn and/or spring

\begin{tabular}{|c|c|c|c|}
\hline Treatment & Treatment date & Days to green tip ${ }^{w}$ & Ascospores (\% reduction) \\
\hline Pre-leaf fall ureay & 12 Oct 89 & $\ldots$ & $97 \mathrm{a}$ \\
\hline Autumn post-leaf fall urea & 8 Nov 93 & $\ldots$ & $42 \mathrm{~b}$ \\
\hline Autumn post-leaf fall urea & 16 Nov 95 & $\ldots$ & $58 \mathrm{a}$ \\
\hline Spring urea ${ }^{z}$ & 2 May 90 & ?? & $84 \mathrm{a}$ \\
\hline Spring urea & 14 Apr 92 & 8 & $71 \mathrm{a}$ \\
\hline Spring urea & 21 Apr 93 & 2 & $65 \mathrm{~b}$ \\
\hline Spring urea & 8 Apr 94 & 10 & $44 \mathrm{a}$ \\
\hline Spring urea & 6 Apr 95 & 18 & $86 \mathrm{a}$ \\
\hline Autumn leaf shred & 16 Dec 91 & $\ldots$ & 34 \\
\hline Autumn leaf shred & 17 Nov 92 & $\ldots$ & $91 \mathrm{a}$ \\
\hline Autumn leaf shred & 9 Nov 93 & $\begin{array}{l}\cdots \\
\cdots\end{array}$ & $84 \mathrm{a}$ \\
\hline Autumn leaf shred & 7 Nov 94 & $\ldots$ & $81 \mathrm{a}$ \\
\hline Spring leaf shred & 26 Mar 92 & 27 & $50 \mathrm{a}$ \\
\hline Spring leaf shred & 20 Apr 93 & 3 & $82 \mathrm{a}$ \\
\hline Spring leaf shred & 5 Apr 94 & 13 & $85 \mathrm{a}$ \\
\hline Spring leaf shred & 3 Apr 95 & 21 & $82 \mathrm{a}$ \\
\hline \multirow{2}{*}{ Autumn + spring leaf shred } & $16 \operatorname{Dec} 91$ & $\ldots$ & $57 \mathrm{a}$ \\
\hline & 26 Mar 92 & 27 & \\
\hline \multirow{2}{*}{ Autumn + spring leaf shred } & 17 Nov 92 & $\ldots$ & $89 \mathrm{a}$ \\
\hline & 20 Apr 93 & 3 & \\
\hline \multirow[t]{2}{*}{ Autumn + spring leaf shred } & 9 Nov 93 & $\ldots$ & $89 \mathrm{a}$ \\
\hline & 5 Apr 94 & 13 & \\
\hline \multirow[t]{2}{*}{ Autumn + spring leaf shred } & 7 Nov 94 & $\ldots$ & $79 \mathrm{a}$ \\
\hline & 3 Apr 95 & 21 & \\
\hline
\end{tabular}

${ }^{\mathrm{w}}$ Days from treatment in spring to the green tip stage of fruit bud development.

"Mean number of ascospores trapped followed by "a" is significantly different from untreated check at $P=0.05$; number followed by "b" is significantly different from check at $P=0.1$.

y Ascospores were trapped from scabbed leaves treated with urea that had been placed on a sod lawn on 24 April 1990.

${ }^{\mathrm{z}}$ Ascospores were trapped from scabbed leaves that had been placed on a sod lawn on 2 May 1990 and treated with urea. among the commercial orchards is attributed to the percentage of the orchard floor shredded and the influence of ground cover characteristics on the shredding process. Leaves were shredded most effectively at sites where ground cover in the orchard had been well-managed prior to leaf fall. Poor in-row weed management and tall grass in the drive row were associated with fewer shredded leaves and larger pieces of shredded leaves.

Potential of autumn shredding to reduce the number of ascospores and amount of disease if all leaf litter were shredded. The estimated potential reduction of RAD at the MR site and the AC site in the large-plot study is comparable to the reductions of ascospores trapped in the small-plot study. If all potential reductions of ascospores and foliar lesions resulting from autumn shredding in the large-plot study are averaged, shredding leaf litter over the entire orchard floor in autumn is estimated to have the potential to reduce the risk of scab by $77 \%$. This is comparable to the $72 \%$ average reduction in number of ascospores over 4 years in the autumn leaf-shredding plots in the smallplot study. The reductions in the number of ascospores trapped in 1992 in the smallplot study are considerably less than in the other 3 years and are believed due to the very late treatment (16 December). The $85 \%$ average reduction in number of ascospores for the other 3 years probably best reflects the potential to reduce the number of ascospores by shredding leaves in autumn, when $95 \%$ of the leaves had fallen under conditions present in the northeastern United States.

The percent reduction of leaf litter density due to sanitation should not be expected to be linearly related to the percent reduction in the number of ascospores or primary scab lesions. This is because the sanitation treatment may reduce the number of ascospores in the leaf litter that remains through its detrimental effect directly on the pathogen or through its effects on microbial organisms that are in some way detrimental to $V$. inaequalis. Also, some shredded leaf pieces would not have the normal horizontal orientation of leaves on the orchard floor that allows ascospore discharge upward into the orchard air, thus resulting in an immediate loss of some discharged ascospores. The autumn leaf-shredding trial at the AC site in 1986-87 provides the only data to compare the relationship between the reduction in amount of leaf litter and the reduction of ascospores and lesions. The greater reduction of ascospores, lesions on seedlings, and lesions on trees, compared with the reduction of leaf litter, could be accounted for by any of the possibilities discussed above.

Nearly all of the leaf litter was shredded at the KY site in 1990, so the results may indicate the potential effectiveness of 
spring shredding to reduce the number of ascospores and primary lesions on leaves. The spring treatment was evaluated only 1 year in the large-plot study, but the $89 \%$ reduction in number of ascospores was comparable to the $83 \%$ reduction in number of ascospores in the three spring leafshredding treatments in April in the smallplot study.

Reduction in number of foliar and fruit scab lesions. The percent reduction in number of lesions in orchard trees may not have identified a treatment's full effect on lowering the primary inoculum. The first fungicide was not applied until petal fall or fruit set at five sites (after two to six infection periods had occurred), so secondary lesions resulting from infections by conidia produced on primary lesions may have been included in the assessment. If so, the percent reduction in number of lesions in the sanitation plots would have been less than would have occurred if only primary inoculum had been present. However, shredding was not very effective in reducing the amount of leaf litter at the AW site, and that could also account for the low reduction in number of lesions. Placement of seedling trees in treatment and check plots for 1 day during a rain event in the primary season overcomes the uncertainty of inoculum source because the seedlings were placed in row alleys outside tree canopies. Most, if not all, lesions would be expected to develop from infections by ascospores, because conidia are splash-dispersed mainly within a tree's canopy. Thus, the estimated $92 \%$ potential reduction in number of foliar lesions on seedlings placed in the two autumn-shredded plots on 8 rainy days may be a better indication of the potential of autumn shredding to reduce the risk of primary scab.

Potential use of sanitation in integrated pest management (IPM) programs. The relationship between the concentration of airborne ascospores of $V$. inaequalis and the number of lesions that develop is linear (4), so the percent reduction of airborne ascospores collected from treated leaves is also a measure of the percent reduction in lesions one can expect. With respect to scab management, the percent reduction in number of ascospores can be considered to identify the percent reduction in the risk of primary scab. Shredding the leaf litter or treating the leaf litter with urea in autumn or early spring before bud break should, conservatively, reduce the risk of primary scab by $50 \%$. Thus, there would be $50 \%$ fewer lesions developed on leaves and fruit from each primary infection period. Is this reduction sufficient to make sanitation economically feasible, and when is sanitation justified?

Potential ascospore dose (PAD) is defined as the predicted production of ascospores per square meter of orchard floor (14). MacHardy $(35,36)$ proposed an action threshold based on PAD and a sanitation threshold that related to the PAD action threshold. The PAD action threshold stated that an orchard assessed at $\leq 600$ PAD could be left untreated by fungicide until pink unless three infection periods occurred before pink. The sanitation action threshold is a range of predicted ascosporic inoculum (PAD) above the PAD action threshold within which sanitation would reduce the PAD to below the PAD action threshold and, as a consequence, allow a reduction in the fungicide dose needed to control scab. This would provide economic justification for a sanitation treatment.

The incidence of foliar scab lesions in autumn is the most variable input in calculating PAD. Analysis of the relationship between the autumn assessment and the number of early-season infection periods that could be left unprotected by fungicide without increasing the incidence of scabbed fruit at harvest has resulted in a scab-risk action threshold based only on the autumn assessment, rather than a calculation of PAD (48). The scab-risk action threshold states that if the number of scabbed leaves on 600 extension shoots is $\leq 50$, the first fungicide spray can be delayed until pink or until after three infection periods, but before the fourth infection period, whichever comes first. When all reductions of ascospores, leaf litter, and lesions in the sanitation plots are considered, a conservative reduction of risk resulting from a sanitation treatment is estimated to be $50 \%$. This reasoning is the basis for the following sanitation action threshold related to the action threshold stated above: if the number of scabbed leaves in the autumn assessment is 50 to 100 , the grower should select a sanitation treatment (leaf shredding or urea), perform the treatment, and delay the first fungicide spray according to the action threshold (48). If the number of scabbed leaves in an autumn assessment is greater than 100, the full-season fungicide program to control scab should be followed (48). The sanitation action threshold is based on the conservative estimate of reduced risk. It excludes orchards with an autumn assessment of 100 to 200 scabbed leaves on 600 shoots that would qualify for a sanitation program if the effectiveness of sanitation in reducing risk was set at $80 \%$. Reducing the risk of scab $80 \%$ is equivalent to having $80 \%$ fewer scabbed leaves in the leaf litter and may be justified if (i) the orchard has moderate scab (100 to 200 scabbed leaves on 600 shoots) and tree and ground cover features associated with the greatest reductions in numbers of ascospores and lesions and (ii) sanitation can be performed at the time of year the treatment has shown to be most effective. For other regions, the results are suggestive that a reduction in risk of scab greater than $80 \%$ is likely if (i) leaf fall allows a longer interval between an autumn sanitation treatment and the onset of winter conditions, (ii) the winters are milder, (iii) there is little or no snow cover, and (iv) the winters are not too dry. Shredding the leaf litter in autumn or spring with a flail mower is a promising new sanitation practice, but modification that permits nearly complete shredding is needed to achieve a reduction in scab risk greater than $80 \%$.

\section{ACKNOWLEDGMENTS}

This project was supported by Hatch Act funds and a Northeast Regional IPM competitive USDACSRS Special Grant. We thank William Doe of Doe Ag Sales for his generous contribution of time and equipment, Christopher Neefus, Biometrics, UNH, for his assistance with statistical analysis, and the following growers and farm managers for their cooperation: Jamie Breen, Russel Cross, Chip Hardy, Art Kelley, Erick Leadbeater, and Peter Wagner. Scientific contribution 2070 from the New Hampshire Agricultural Experiment Station.

\section{LITERATURE CITED}

1. Aderhold, R. 1894. Die Perithecienformen von Fusicladium dentriticum Wallr. (Venturia chlorospora f. Mali). Ber. Dtsch. Bot. Ges. 12:338-342.

2. Aderhold, R. 1895. Litterarische Berichtigung zu dem Aufsatze ueber die Perithecienform von Fusicladium dendriticum Wallr. Ber. Dtsch. Bot. Ges. 13:54-55.

3. Aderhold, R. 1897. Revision der species Venturia chlorospora, inaequalis und ditricha autorum. Hedwigia 36:81.

4. Aylor, D. E., and Kiyomoto, R. K. 1993. Relationship between aerial concentration of Venturia inaequalis ascospores and development of apple scab. Agric. For. Meteorol. 63:133-147.

5. Bassino, J. P., and Blanc, M. 1975. La tavelure du pommier: Amelioration de la lutte par la destruction de la forme hivernante du champignon. Def. Veg. 174:149-153.

6. Burchill, R. T. 1968. Field and laboratory studies of the effect of urea on ascospore production of Venturia inaequalis (Cke.) Wint. Ann. Appl. Biol. 62:297-307.

7. Burchill, R. T., and Swait, A. A. J. 1977 Eradication of the perithecial stage of apple scab with surfactants. Ann. Appl. Biol. 87:229-231.

8. Carreño, I., and Pinto de Torres, A. 1982 Efecto de las pulverizaciones otoñales de urea en la reducción del inoculo primario de Venturia inaequalis (Cke.) Wint., en manzanos de la zona de Curocó, Chile. Agric. Tec. 42:235238.

9. Cook, R. T. A. 1969. Studies on the overwintering of Venturia inaequalis (Cke.) Wint. Ph.D. diss. University of London, England.

10. Curtis, K. M. 1924. Black spot of apple and pear. N.Z. J. Dep. Agric. 28:21-28.

11. Darpoux, H., Lebrun, A., and de la Tullaye, B. 1975. Action de traitements sur la formation des peritheces et la production de l'inoculum primarie de Venturia inaequalis (Cke.) Wint et Venturia pirina Adher. Phytiatr. Phytopharm. 24:3-14.

12. Gadoury, D. M., and MacHardy, W. E. 1982. Effects of temperature on the development of pseudothecia of Venturia inaequalis. Plant Dis. 66:464-468.

13. Gadoury, D. M., and MacHardy, W. E. 1985. Negative geotropism in Venturia inaequalis. Phytopathology 75:856-859.

14. Gadoury, D. M., and MacHardy, W. E. 1986. Forecasting ascospore dose of Venturia inaequalis in commercial apple orchards. Phytopathology 76:112-118.

15. Gadoury, D. M., MacHardy, W. E., and Ro- 
senberger, D. A. 1989. Integration of pesticide application schedules for disease and insect control in apple orchards of the northeastern United States. Plant Dis. 73:98-105.

16. Goldsworthy, M. C., Dunegan, J. C., and Wilson, R. A. 1949. Control of apple scab by ground and tree applications of eradicant fungicides. Plant Dis. Rep. 33:312-318.

17. Gupta, G. K. 1979. Role of on-season, post harvest and pre leaf fall sprays in the control of apple scab (Venturia inaequalis). Indian J. Mycol. Plant Pathol. 9:141-149.

18. Gupta, G. K., and Lele, V. C. 1980. Role of urea in suppression of ascigerous stage, and comparative in-vitro efficacy of fungicides against apple-scab. Indian J. Agric. Sci. 50:167-173.

19. Hirst, J. M., and Stedman, O. J. 1962. The epidemiology of apple scab (Venturia inaequalis [Cke.] Wint.) III. The supply of ascospores. Ann. Appl. Biol. 50:551-567.

20. Holz, W. 1938. Versuche zur Bekampfung der Perithezien von Fusicladium dendriticum (Wallr.) Fckl. mittels kalkstickstoff. Zentralbl. Bakteriol. 97:23-26, 466-469.

21. Kadow, K. J., and Hopperstead, S. L. 1941. Ground sprays aid in control of apple scab. (Abstr.) Phytopathology 31:13.

22. Keitt, G. W. 1930. Fall applications of fungicides in relation to apple-scab control. (Abstr.) Phytopathology 20:122.

23. Keitt, G. W. 1935. Progress in the development of eradicant fungicides. (Abstr.) Phytopathology 25:23.

24. Keitt, G. W. 1939. Toxicity of the sodium salt of dinitro-o-cresol to Venturia inaequalis. Science 90:139-140.

25. Keitt, G. W., Clayton, C. N., and Langford, M. H. 1940. Eradicant fungicidal treatments in relation to apple-scab control. (Abstr.) Phytopathology 30:13.

26. Keitt, G. W., Clayton, C. N., and Langford, M. H. 1941. Experiments with eradicant fungicides for combating apple scab. Phytopathology 31:296-322.

27. Keitt, G. W., Clayton, C. N., and Moore, J. D. 1941. Experiments with eradicant fungicides in relation to apple-scab control. (Abstr.) Phytopathology 31:13-14.

28. Keitt, G. W., and Moore, J. D. 1943. Experiments with eradicant and protectant sprays for apple scab control in 1942. (Abstr.) Phytopathology 33:6.

29. Keitt, G. W., and Palmiter, D. H. 1937. Eradicant fungicides in relation to apple scab control. (Abstr.) Phytopathology 27:133.

30. Keitt, G. W., and Palmiter, D. H. 1937. Poten- tialities of eradicant fungicides for combating apple scab and some other plant diseases. J. Agric. Res. 55:397-436.

31. Keitt, G. W., and Wilson, E. E. 1927. A possible reorientation of aims and methods for apple scab control. (Abstr.) Phytopathology $17: 45$.

32. Keitt, G. W., and Wilson, E. E. 1928. Fall applications of fungicides in relation to apple scab control. (Abstr.) Phytopathology 18:146.

33. Keitt, G. W., and Wilson, E. E. 1929. Third progress report of studies of fall applications of fungicides in relation to apple scab control. (Abstr.) Phytopathology 19:87.

34. Louw, A. J. 1948. Fusicladium of apples, IV. Can this disease be stamped out? Farming S. Afr. Jan., pp. 28-32.

35. MacHardy, W. E. 1994. A "PAD" action threshold: The key to integrating practices for managing apple scab. Pages 75-82 in: Integrated Control of Pome Fruit Diseases. Denis J. Butt, ed. Norw. J. Agric. Sci. Suppl. 17.

36. MacHardy, W. E. 1996. Apple Scab. American Phytopathological Society, St. Paul, MN.

37. MacHardy, W. E. 1998. Action thresholds increase fungicide and sanitation efficiency in integrated management of apple scab. Proc. Int. Congr. Plant Pathol. 7th.

38. MacHardy, W. E., and Gadoury, D. M. 1986. Patterns of ascospore discharge by Venturia inaequalis. Phytopathology 76:985-990.

39. MacHardy, W. E., and Sondej, J. 1981. Weather-monitoring instrumentation for plant disease management programs and epidemiological studies. N.H. Agric. Exp. Stn. Bull. 519.

40. MacHardy, W. E., Gadoury, D. M., and Rosenberger, D. A. 1993. Delaying the onset of fungicide programs for control of apple scab in orchards with low potential ascospore dose of Venturia inaequalis. Plant Dis 77:372-375.

41. MacHardy, W. E., and Sutton, D. K. 1995. Integrating sanitation practices with fungicide applications to reduce fungicide dose in controlling apple scab. Abstr. 3011/0523 in: Proc. Int. Plant Prot. Congr. XIII.

42. May, K. R. 1945. The cascade impactor: An instrument for sampling coarse aerosols. J. Sci. Instr. 22:187-195.

43. Miedtke, U. 1990. Eradikative Bekämpfung der Ascosporembildung von Venturia inaequalis, dem Erreger des Apfelschorfes, durch Cyanamid. 71.

44. Miller, P. M. 1970. Reducing discharge of ascospores of Venturia inaequalis with a spring application of benomyl, thiabendazole, or urea. (Abstr.) Plant Dis. Rep. 54:27.
45. Miller, P. M., and Rich, S. 1968. Reducing spring discharge of Venturia inaequalis ascospores by composting overwintering leaves. Plant Dis. Rep. 52:728-730.

46. Moller, W. J. 1981. Efficacy of autumn urea in reducing spring inoculum of apple scab. Calif. Plant Pathol. 52:1-2.

47. Montealegre, J. A., and González, S. M. 1983. Tratamientos otonales y sus effectos en la produccion de inoculo primario de Venturia inaequalis (Cooke) Winter en Valdivia. Agro. Sur. 11:1-4.

48. New England Apple Pest Management Guide, 1999-2000. 1999. New Engl. Apple Pest Manage. Guide, 1999-2000. G. W. Koehler, ed. University of Maine, Orono.

49. Oland, K. 1963. Responses of cropping apple trees to post-harvest urea sprays. Nature 198:1282-1283

50. Palmiter, D. H. 1940. Eradicant treatments as an aid in the control of apple scab. (Abstr.) Phytopathology 30:18.

51. Palmiter, D. H. 1946. Ground treatments as an aid in apple scab control. N.Y. Agric. Exp. Stn. Bull. 714.

52. Palmiter, D. H., and Keitt, G. W. 1936. Progress of studies of eradicant fungicides in relation to apple scab control. (Abstr.) Phytopathology 26:103-104.

53. Scribner, F. L. 1886. Fungous diseases of plants. U.S. Dep. Agric. Annu. Rep. 1885.

54. Scribner, F. L. 1888. Apple scab. U.S. Dep. Agric. Annu. Rep. 1887. pp. 341-347.

55. Seidl, V. 1983. K otázce úcinnosti mocoviny aplikovane $\mathrm{v}$ dobe vegetachíno klidu na strupovitost jablone (Venturia inaequalis $\mathrm{Cke}$ Wint.). Vedecké Práce Ovocnárské 9:175-182.

56. Sutton, D. K., and MacHardy, W. E. 1993. The reduction of ascosporic inoculum of Venturia inaequalis by orchard sanitation (Abstr.) Phytopathology 83:247.

57. Trelease, W. 1884. The apple scab and leaf blight. Annu. Rep. Wis. Agric. Exp. Stn. 1:45 56.

58. Vojvodic, D. 1970. Ispitivanje uticaja kasnog jesenjeg prskanja na formiranje peritecija Venturia inaequalis (Cke.) Wint. Zast. Bilja 21:151-155.

59. Zuck, M. G., and Caruso, F. L. 1984. A volumetric spore trap designed for monitoring Venturia inaequalis spore release in apple scab management programs. (Abstr.) Phytopathology 74:796.

60. Zuck, M. G., and MacHardy, W. E. 1981. Recent experience in timing sprays for control of apple scab: Equipment and test results. Plant Dis. 65:995-998. 